\title{
The Senses in Philosophy and Science: From the Nobility of Sight to the Materialism of Touch
}

\author{
DANIJELA KAMBASKOVIC AND CHARLES T. WOLFE
}

One of the greatest difficulties in Physics lies in understanding the operations of the senses.

Mersenne 1636, I.v.1, prop. LI: 79

Someone should write a book on the epistemology of the sense of touch.

Bennett 1971: 102

The hands-despised for their materialism.

Diderot 1975-, IV: 140

The choice of a particular sense in the construction of a metaphysical hierarchy, a rank-ordering of the world, is a classic motif, on display notably in the Platonic and Aristotelian privileging of sight as the noblest of senses. The meaning of theoria as contemplation takes center stage here, with the thinker being defined by her contemplative distance from the object experienced; 
indeed, most Indo-European terms for mental activity apparently derive from words for vision or the visible (Biernoff 2002: 66). To privilege one sense is of course to downgrade others. If sight is privileged in the idealist philosophical tradition, as the contemplation at a distance of the objects of perception, touch, the contact sense, the dirty sense, is all the way at the other extreme. This is the case, whether in a libertine sense or in the way early modern "empiricks" or barber-surgeons get their "hands dirty," whereas learned professors of medicine do not (including by touching someone's beating heart, as William Harvey describes in his encounter with the nobleman Hugh Montgomery, whose heart was covered with a metal plate after a wound that healed, leaving an opening (Harvey 1653, Ex. 52; Salter and Wolfe 2009).

Touch is spread throughout the body and is the least abstract, and therefore basest. But, as shown by medieval and early modern theological debates regarding the pivotal role of touch in following the path of virtue or vice, not all is bad. Touch may be spread throughout the body, but it is also located in the hand, the focus of worthy and noble human activities. In The Allegory of Touch (1618; one of five paintings representing each of the senses, a collaboration between Rubens and Breughel the Elder), Elizabeth Harvey has called attention to the hand's crucial role as an organ of touch that bridges mind and body, showing how it oscillates in the image with a more diffuse somatic theme: the protective armor that shields the body from harm. She quotes John Bulwer asserting, in his Chirologia; or, The Naturall Language of the Hand (1644), that the hand is the "Spokesman of the Body," speaking a universal language that is understood by all (Bulwer 1644: 2-3, in Harvey 2011: 396). The hand defines the self, as it is impossible to touch without being touched. It takes on the role of a teacher of the mind, both through pleasure, and through the pain that it gives.

Other senses have other narratives and other valuative investments. Martin Luther constructed an entire metaphysics of hearing, for the Word is not something to be seen or touched, but heard (see the analysis of Luther and Kant in Schürmann 2003). Luther glosses Matthew 11:15 and Revelation 2:7 as:

He that hath ears to hear, let him hear, and he that doth not, let him be left behind, earless, unhearing, deaf," and "a right faith goes right on with its eyes closed; it clings to God's Word; it follows that Word; it believes the Word even when all creatures are against it, even if it should seem to the flesh that nothing is less likely to happen than what the Word wants believed.

Lectures on Jonah 1:1, in Luther 1974, 19: 8, emphasis added 
The distantiation-function inherent in hearing-as I wait to hear The Word-is used by Luther as a counterpoint to both the idealism of the scholastic theologians and the naïve "touch" empiricism of the humanists. The theologian and natural philosopher Marin Mersenne also deemed hearing a better, more reliable sense than sight or touch, which often cannot distinguish between bodies, and sounding rather like Luther, added that "this may be why God wanted revealed truths to be received by the ear, which is less likely to be deceived than the eye" (Mersenne 1636, I.i, prop. XI: 20).

Taste and smell are subject to equally contrasting interpretations, but tend to be associated with our animal nature. It would appear that no sense is immune to the essential ethical ambiguity that characterizes human life. In this chapter we examine some key moments in the evaluative metaphysics of the senses-the role a given sense will play in the construction of a metaphysics but also a system of value-in the centuries prior to the emergence of a unified, experimental life science. We pay particular attention to sight (including optics), unsurprisingly, but also to touch, which has often been the "poor relative" of sight and hearing-an opposition which Bakhtin famously presented as that between high and low culture, in his project to exhume a history of the body and its urges: a Rabelaisian, explosive body with its socially destabilizing potential (Bakhtin 1984). Moments of the revalorization of touch discussed here-sometimes provocative, sometimes innocent-include medicine, theater, and metaphysics.

After all, no less a philosopher than the very ahistorical Jonathan Bennett recommended that "Someone should write a book on the epistemology of the sense of touch" (Bennett 1971: 102)—for it is not just Plato, Descartes, or the metaphysics of light: philosophy per se tends to privilege sight. But unlike Bakhtin or, today, mentalité-inspired historians like Alain Corbin (Corbin 1988), we won't try to reconstruct particular historical regimes of the senses. Our attempt, if fleshed out further, would be closer to what John Sutton calls "historical cognitive science," which "works between two projects": "the analysis of other and older theories of mind, how they relate to and differ from current approaches, and what forgotten or neglected explananda they bring into focus" but also, "relating to cognitive practices rather than theories": "the task of working out how such views about mind and self reflect or partly cause different historical forms of mental activity" (Sutton 2000: 117). One might hear echoes here of Benjamin's inquiries into the historicity of perception, in his celebrated 1936 essay "The work of art in the age of mechanical reproduction" (Benjamin 1968) and throughout his writings (on Baudelaire, Paris, photography, etc.), which 
themselves may echo Marx's own intuitions regarding the historicity of the senses (Howes 2005).

A papyrus purchased in Cairo in 1901 by Ludwig Borchardt, upon examination, contained two distinct texts (recto and verso), the second of which was the work of an author whose hitherto unknown or missing works had led him to be excluded from the front ranks of Stoicism: Hierocles, a major disciple of Chrysippus (Heller-Roazen 2007: 117ff.). In this verso text, Hierocles comes closer than perhaps any other author before the early modern materialists to expressing the knot which binds together the senses and the world of value: "Sensation [aisthessis] contributes to the knowledge of the first thing that is one's own and familiar and it is precisely that discourse which we have said constitutes the best principle for the elements of ethics" (1.36, in Heller-Roazen 2007: 119). To the above-mentioned investigations into the historical, cognitive, affective sedimentation of particular sensory regimes (à la Febvre) we add the metaphysical, valuative dimension that Hierocles orthogonally points to: the senses as construction and valorization of a world.

\section{THE NOBILITY OF SIGHT AND THE SOLAR EYE}

The Platonic and Aristotelian sources of medieval and Renaissance thought (and beyond) privilege sight and depreciate touch. Plato spoke of "the eye of the soul" (Republic VII, 527d), also equating the eye with the sun, and allocating this organ the highest ethical capacity. Aristotle famously interwove sight, contemplation, and philosophy itself at the beginning of the Metaphysics:

"We prefer sight, generally speaking, to all other senses ... [O ]f all the senses, sight best helps us to know things, and reveals many distinctions" (Met. A, 980a25), and was hostile to natural philosophers such as Democritus who "represented all perception as being by touch" (De sensu 4, 442a29; Kirk et al. 1983: 428), even if he elsewhere stressed that he was located in between the phusiologoi and the Lovers of the Forms. When writing in a biological mode, he privileged touch much more: "the organ of touch," "correlated to several distinct kinds of objects," is "the least simple of all the sense-organs" (De part. anim. II 1, 647a15). But the predominant understanding passed on by these texts is that sight is privileged because it is 'eidetic': it is a grasping of essences. ${ }^{1}$ In Hans Jonas's terms, sight alone allows the distinction between the changing and the unchanging, whereas "all other senses operate by registering change and cannot make that distinction. Only sight therefore provides the sensual basis on which the mind may conceive of the idea of the eternal, that which never changes and is always present" (Jonas 1966: 145). The privileging of 
sight runs through various prestigious moments in Western metaphysics and science, from Aquinas' Summa Theologica:

Those senses are most concerned with beauty which are most concerned in apprehension, namely sight and hearing, which ministers to reason. For we speak of beautiful sights and sounds but do not give the name of beauty to the objects of other senses, such as tastes or smells ... what simply satisfies desire is called good, but that whose very apprehension pleases is called beautiful

II.1. xxvii

to Leonardo in a fragment of his Libro di Pittura asserting the primacy of vision, and by extension of painting over any other kind of art or science:

And if you call painting dumb poetry, the painter may call poetry blind painting. Now which is the worse defect? to be blind or dumb? Though the poet is as free as the painter in the invention of his fictions they are not so satisfactory to men as paintings; for, though poetry is able to describe forms, actions and places in words, the painter deals with the actual similitude of the forms, in order to represent them ... And if the poet gratifies the sense by means of the ear, the painter does so by the eye-the worthier sense.

16 a-b, in Leonardo 1888/1970, I, ix (The Practice of Painting), $\mathbb{S} \mathbb{S 6 5 3 - 4}$

Similar enthusiasm resonates through the major figures of the New Science: Kepler wrote to Galileo in 1610 that Bruno was more "godlike" than them; they were his followers because his insights were arrived at without even seeing the phenomena (Kepler 1610: 10 recto). Such appeals to the mind's eye resonate with the metaphysics of light, from Plotinus to Renaissance Neoplatonism. André Du Laurens, the physician to King Henri IV, described sight as the noblest object, "born from the heavens," "God's eldest daughter" (Du Laurens 1597: f. 24r). We can still hear this centuries later, in Goethe: "If the eye were not solar / How would we perceive light" (Goethe 1970, Introduction, liii). ${ }^{2}$

Galileo, in The Assayer (1623), analysed the senses and secondary qualities in corpuscular-mechanistic terms, in order to reduce them to primary qualities; he discussed the microstructure of taste and touch but was careful to repeat that sight is the "most excellent and noble of the senses," related to light itself (Drake 1957: 277, translation modified). For the great neuroanatomist Thomas 
Willis, "Seeing" was "the most noble Power, because this faculty apprehends things at a great distance, under a most subtil Figure, by a most clear perception, and with great delight," "next in virtue to the Eternal and Immaterial Soul," embracing bodies within "Heaven and Earth in a Moment," "far remote from our touch," although he then expresses gentle irony about the claim (Willis 1683, XV, "Of the sight": 75). Sight is the most noble sense, also due to its "great distance"; for Robert Hooke, too, of the "differing ways of Sensation," "the 1st and most Spiritual is plac'd in the Eye" (the fifth is "over the whole Body"; Hooke 1705: 12). Kepler, Galileo, Willis, and Boyle perform a metaphysical valorization of sight which occasionally resembles a mystical commitment, yet they are also giants of the New Science, in a fitting testimony to the hybridity of genres.

On this view, sight is the purest, most philosophical sense; it is closest to light (hence the equation between theoria and contemplation, sight and intellection). Attribution of ethical perfection to sight may also indirectly have affected the organization of societal codes of appearance. Failure to wear colors and fabrics prescribed for particular stations in society has been associated with social disarray and uncertainty, and brought on severe repercussions since ancient times. Jewish Holy Commandments, for instance, stipulate that "women must not wear male clothing nor men that of women" and command lepers to always appear "bareheaded with clothing in disarray so as to be easily distinguishable"; ${ }^{3}$ in late medieval Florence and Venice, laws were passed in both cities outlawing cross-dressing by prostitutes as males to attract customers (Ruggiero 1993: 25); and in sixteenth-century England, Parliament regulated color-coding enabling the viewer to determine rank of individuals on sight (Hager 1991: 4), with the association of status and rank with the specific fabric worn regulated personally by the monarch. ${ }^{4}$

As regards the hierarchy of the senses, this privileging of sight is clearly opposed to the Epicuro-Lucretian valorization of touch, from antiquity via Rabelais to Julien Offray de La Mettrie's materialism. For Lucretius, touch is primary, it is "the sense of the body" (De rerum natura, II, 434), which further implies that "the nature of the soul and of the mind is corporeal": touch requires materiality, hence there must be something in the mind/soul (animus, anima) which is material (III, 161-6). This valorization of touch is present in Gassendi's invocation of bodily experience against Descartes in his Objections to the Meditations, and in the Epicurean physician Walter Charleton, for whom "All Sensation is a kind of Touching" (Charleton 1966, III, ix: 248, which implies, contrary to Rey 1995, that it was not in Le Cat's 1740 Traité des sensations that sight and hearing were first reduced to touch). It is a 
recurrent motif in a minority line of early modern thinkers (often physicians), running through Guillaume Lamy and La Mettrie. Prominent medical figures such as William Harvey and Franciscus de la Boë Sylvius also praise touch (see below), but without these radical Epicurean overtones or underpinnings.

Yet even if we do not "stoop" to the base materialism of touch, sight itself is not master in its own house: it is fickle, and it allows for a process of mechanization which demystifies—one might even say "secularizes"-the solar eye.

\section{THE FICKLENESS OF SIGHT AND THE MECHANIZATION OF VISION}

Renaissance treatises on painting point, also, to the moral fickleness of sight. Leon Battista Alberti described perspective as an exercise in representing an objective, but also a deeply subjective, reality. "The painter," Alberti wrote, "strives solely to fashion that which is seen; anything which exists on a surface so that it is visible"; "no one would deny that the painter has nothing to do with things that are not visible" (Alberti 1956, I: 42). Shakespeare throws light on this interplay between the mirage of "objective truth" arising from a deeply subjective viewpoint, which not only engages with treatises on perspective, but also foreshadows tenets of philosophical relativism. "The truth" emerging from what is seen, in Alberti's phrase, becomes redefined in Shakespeare's Sonnets as the question of refraction through a unique artistic consciousness. There, Shakespeare advocated awareness of "the painter's skill," rather than uncritical immersion; such critical awareness, he seemed to suggest, serves to enhance the exquisite, morally complex and formative experience of seeing through, and beyond, an individual artistic take on the "truth" and "value" of what is seen:

Mine eye hath played the painter and hath steeled

Thy beauty's form in table of my heart;

My body is the frame wherein 'tis held,

And perspective that is best painter's art.

For through the painter must you see his skill

Sonnet $24,1-5$

The fickleness of perspective can be translated to the dramatic space as well. Everyone can see Hamlet's father's ghost in the opening scene of the play; but later, in the bedroom scene with his mother, Hamlet is the only one who can see it (Shakespeare 1997: 3.4: 107). In this scene, for Hamlet, the ghost's 
appearance is "reality"; but from Gertrude's perspective, Hamlet addressing empty space looks very much like his madness. Shakespeare is asking here whether something can ever be considered "real" or "true" if only one person can see it; in other words, he questions the limits of vision as the purveyor of truth, and proposes that visual phenomena require social confirmation before they can be accepted.

Indeed, to turn to a central figure of the New Science, even Descartes, who stated in his treatise on optics, the Dioptrics (1637), that "it is the soul that sees, not the eyes" and, right at the start of the treatise, that "The entire conduct of our life depends on our senses, amongst which that of sight is the most universal and noble," "5 lays out a vast project for demystifying vision.

The science of optics grapples in its own way with this tension between a metaphysics of light and a demystification of the sense of sight-including Kepler's unique conceptualization of the eye as an optical instrument. An issue had been the transmission of information through vision, the "age-old problem of contact between the observer and the visible object" (Lindberg 1976: 39): was there a "flow of material substance," in which the medium is all-important, or rather chiefly an act of seeing by the organ of the eye? For Leonardo, to take an example, "sight is exercised by ... the mediation of light ... the senses which receive the image [similitudini] of things do not send forth from themselves any power" (Leonardo da Vinci [1888] 1970, II: 99). Kepler, in Ad Vitellionem Paralipomena (1604), relying on the anatomical descriptions provided by his contemporaries, tried to account for the diffusion of light through the eye. To elucidate the way light rays propagate inside the eye, Kepler compared it to a camera obscura, with the pupil being like a window and the lens a screen (Kepler [1604] 1968, V, 2); he criticized Della Porta, who was the first to describe the eye as a camera obscura, but thought that the image formed on the lens rather than on the retina. Descartes, in Dioptrics I, says

I would have you consider the light in bodies we call "luminous" to be nothing other than a certain movement, or very rapid and lively action, which passes to our eyes through the medium of the air and other transparent bodies, just as the movement or resistance of the bodies encountered by a blind man passes to his hand by means of his stick.

AT VI: 84 / CSM I: 153

Here, vision is analyzed on the model of touch; a mechanist account of vision requires that the visible be "set at a distance, in order to objectify it" (Bellis 2010, II, i.A.2). Bellis notes that the properly scientific objectification of vision 
in Descartes' Dioptrics is matched by its metaphysical distantiation in the Meditations: "I shall consider myself as having no hands or eyes, or flesh, or blood or senses, but as having falsely believed that I had all these things"; "I will now shut my eyes, block my ears, and divert all my senses. I will erase all images of corporeal things from my thoughts" (First Meditation, AT IX-1: 18 / CSM II: 15, emphasis added; Third Meditation, AT IX-1: 27 / CSM II: 24). The figure of the blind man here (differently from its later usage in Molyneux's Problem: if someone born blind is familiarized with the sphere and the cube, will [s] he spontaneously recognize them if his/her sight returns? $)^{6}$ is used as a thought experiment (so to speak), in which the phenomenal qualities of light can be eliminated, and indeed the visible as such. This is mechanization of vision as an ontological reconstruction of the world (Bellis 2010, Ch. II), what Hamou elegantly calls a "déprise du sensible" (Hamou 2002: 72f.), comparable in its boldness to the (symmetrically opposite) Epicurean reconstruction based on touch and materiality.

Such a reconstruction of vision on the model of touch (a form of reductionism) could be tantamount to materialism, perhaps most notoriously in Hobbes' reduction of all sensation, including touch, vision and all of cognition, to a type of motion. As he writes in his autobiography:

I thought continually about the nature of things, whether I was traveling by boat or by coach, or on horseback. And it seemed to me that there was only one true thing in the whole world, though falsified in many ways . . . the basis of all those phenomena which we wrongly say are somethingthe phenomena of sense-impressions, which are offsprings of our skull, with nothing external. And in those internal regions, there could be nothing but motion.

Tuck 1988: 248; for the original translation, Hobbes 1994: lvi-ii

The way Descartes' blind man "sees with his staff” is a kind of extended touch: "one might almost say that they see with their hands, or that their stick is the organ of some sixth sense given to them in place of sight." Once sight becomes percussive, i.e., a form of touch, then touch becomes metaphysically primary; in the previous, typically Aristotelian context, what we grasped in sight are forms of qualities that move across matter-a qualitative change in matter, not a movement of matter itself-and thus transparency, not collision, is fundamental to understanding how sight works. We cannot improve on Catherine Wilson's diagnosis, in which rationalist philosophers: 
move between a conception of vision that they construct as a phenomenon of embodiment, explained, conditioned, and sometimes degraded by its involvement with the material and the corporeally dense, and a conception of vision they construct as an intellective act, implicating geometrical principles, as a way of having while keeping one's distance, as a satisfaction-but of a thirst for light and knowledge. From this melange ... we can extract what prefigurations we like: community or terror; embodiment or transcendence; engagement or dissociation; the active gaze of Augustinian concupiscence; or the retreat into the shadows of philosophy and the colorless, formless world of midcentury ontology.

Wilson 1997: 135

However, it is possible to say that contact senses reduce to touch, without committing oneself to an Epicurean-type ontology in which touch is the preeminent sense (in the metaphysical and ethically laden or "valorized" sense).

This idea of "seeing through one's staff" also extends, in Descartes and beyond, into the theme of the instrumental or artificial enhancement of our cognitive powers (and by extension, Spinoza would add, our power of acting). At the end of the Dioptrics ( AT VI: 226), Descartes speaks approvingly of the advantage we will gain from optical lenses such as the microscope-an optimism explicitly rejected by thinkers such as Locke, who we consider as paramount empiricists (Locke, the physician Sydenham, and others in their milieu were suspicious of the imprecision of these new techniques, but also, more philosophically, of the microworld as a space unsuited for human perception).

Sight is thus gradually demystified, no longer so noble or "solar," which mutatis mutandis makes it easier to imagine increasingly embodied discourses (Wolfe 2012). Yet there is no linear process of unfolding, from one historicoconceptual regime of the senses to the next. For, as has been noted by cultural historians (Bynum 1995), instead of a phobia of touch and a fascination with vision, earlier centuries seem characterized instead by a more "overflowing" presentation of the sensory world, as is fervidly manifest in a singular "incunabulum" of 1499, the anonymous Hypnerotomachia Poliphili. This work, which can be described with equal fairness as a utopian phantasmagoria, an aesthetic treatise, an erotic novel, and a masterpiece of visionary, speculative architecture, tells the story of Poliphilus (the "lover of many things" but also of Polia), who tosses and turns during a restless night after being rejected by his beloved Polia (or "many things"). In Poliphilus's dream-world, he journeys to the utopian location of Cythera, with long descriptions of the buildings 
encountered (and sumptuous woodcuts of these), in a kind of oceanic paean to beauty and the (virtual) promise of the senses. However much sight and touch are in tension (for all the hundreds of prominent statements praising sight, there are almost as many like Robert Burton's declaring that touch is "the most ignoble" of the senses-Burton [1621] 1989, I, vi, "Of the Sensible Soul”), a tension which is partly resolved by reducing the former to the latter, we need to pay attention, if not to the cornucopia of the Hypnerotomachia, at least to the other senses-hearing, taste, and smell.

\section{OF STINK AND CONFETTI, OR, EMBODIMENT}

In his commentary on Plato's Symposium, Ficino described sight and hearing as "spiritual senses," directly linked to the higher human capacity for ethical thought and higher reasoning; any need to involve other senses in the contemplation of the world is classified as appetite (Ficino [1544] 2000: Oration I). This is the reason why Thomas Kyd's sixteenth-century play The Spanish Tragedy describes the courtship of Bel-imperia and Horatio as one which starts virtuously_involving eyes and ears only-and then deteriorates morally though the gradual engagement of all the other senses (Kyd 1987: 2.4.40-55). Late in the sixteenth century, Shakespeare quietly opens the tradition to scrutiny in Titus Andronicus: when Lavinia is raped and her tongue and hands cut off by her violators, she becomes a grotesque embodiment of ideally virtuous feminine sensuality, a move with which Shakespeare questions the validity of such ideals.

In Renaissance England, music, and the sense which perceives it, hearing, were seen as instruments of order or disorder. Order, degree, and harmony in music thus emerge as categories related to harmony of the macrocosm, the universe and the body politic, as well as the microcosm, or the body natural, bound in a cycle of psychosomatic feedback. In Troilus and Cressida, Shakespeare famously used the metaphor of an instrument falling out of tune to illustrate the precariousness of social and universal order (Shakespeare 1997, 1.3: 85-110). The role of the senses, particularly sensory pleasance and hearing, began to be seen as an important source of mental and physical health, but also of disturbance. In his Treatise of Melancholie, a major statement of humoral theory influencing Shakespeare among others, Timothy Bright argued that music will cure "a disordered rage, and intemperate mirth" and brings order which should normally be imparted by reason, but is more easily done by music. As "musicke as it were a magicall charme bringeth to pass in the minds of men, which being forseene of wise lawgivers in the past, they have 
made choice of certaine kindes thereof, and have rejected the other, as hurtful to their common wealthes" (Bright 1586: 248).

If we agree with Luther that hearing can touch the deepest part of the heart, then there must also be dangers associated with being open to words. If the beloved opens her ears, for instance, hears the lover's pleas and is swayed by his praise, she may become amenable to sin. This is a grave danger, and, in this context, hearing also becomes perceived as another gateway for wickedness and excess (on love as danger, see Kambaskovic-Sawers 2012). Examples of this abound in literature. Boccacio's Fiametta writes a lament for all women to hear what happens to women who believe their lovers' sweet promises (Boccaccio 1562). One thinks also of Satan attacking Eve's morals in Milton's Paradise Lost, with his Petrarchan poetic praise.

Not unlike the conundrum of the base touch being situated in the noble hand, the speaking function of the tongue is also placed in the instrument for tasting. Both functions of the tongue are ethically ambiguous, and this ambiguity is well documented in the early modern period and modern-day critical discourse. Dichotomous metaphors involving noise and silence, life and death, succour and injury, are all used to indicate this ethical ambiguity. When "sins of the tongue" are mentioned, this usually refers either to ethics of speech on the one hand, or the soundness of rhetorical construction on the other, rather than gluttony. The mouth, the location of the tongue, is also a problematic place as it is, at once, the seat of life (food, breath) and the location of pleasurable sensations (smell, taste, sensation) leading to the danger of sin.

As the pleasure of eating was ethically questionable, so was its source, food, and by extension, the sense of taste, which of course has Epicurean overtones. On the one hand, wholesome and tasty food is necessary for survival, health, and flourishing of the human body. But on the other, pleasant-tasting food is a category to be treated with caution, as it can become a source of obsession leading to gluttony, one of the seven deadly sins, semantically connected to lust (Vitullo 2010: 106). Imagery of honey used in love poetry suggests purity, natural sweetness, and artistic merit. When taken in moderation, honey "not only cleanseth, altereth, and nourisheth, but also it long time preserveth that uncorrupted, which is put into it" (Elyot 1595: H4r-v). By contrast, the sweetness of sugar, a man-made sweetener, was associated with lies. The Latin confictio means "to fabricate, to cheat, to deceive, and to manipulate," and is the root of the English words confectionary and fiction, but also the Italian word confetti, the art of sugar-coating with the aim of improving the shape and taste of food (Palma 2004: 42). Then there is the solitary pleasure that Spenser's speaker in Amoretti takes in prolonged contemplation of the lady's body: 
... her brest the table was so richly spredd

my thoughts the guests, which would thereon have fedd.

Spenser 1999: 77

The process of being tempted by delectable food is semantically linked to much of the sexual overtones of Renaissance love poetry and religious and medical treatises warning of the spiritual dangers of gluttony.

The sense of smell was associated with cognitive capacity in the form of intuition, engaging the function of what we know today to be the amygdala. Calvin referred to non-verbal, unconscious cognitive processes in his commentary on the Bible, and suggested that the Fear of God must precede the conscious judgment of "the sight of the eyes or the hearing of the ears," and be intuitive, as if smelled out. The Hebrew origin of the word is, in fact, "smell": the Fear of God is a shrewdness that should come intuitively, like awareness of a smell, rather than learned consciously: "The verb (riach) which is here put in the Hiphil conjugation ... is peculiarly applicable to the person of Christ ... Christ will be so shrewd that he will not need to learn from what he hears, or from what he sees; for by smelling alone he will perceive what would otherwise be unknown" (Calvin 1609, Ch. 11: 120-1).

Moral judgment is often implied in early modern literary metaphors involving a sense of smell, as in Hamlet's observation that "something is rotten in the state of Denmark" (Hamlet, 1.4: 67). The Garden of Eloquence, a 1577 handbook on rhetoric (revised 1593), makes clear the ethical implications of Shakespeare's usage of such a symbol, explaining that "that abominations of sinne do stink and are odious to God and all good men" (Peacham 1593: 5). Faecal matter can also serve as a symbol of moral purging. Sir Philip Sidney often refers to "rhubarb words" in Astrophil and Stella-they allow him to purify his soul of all the foul-smelling, putrefying love and hatred that Astrophil feels for Stella-and the smell of faecal matter is often invoked in political context (Smith 2012: 5).

\section{THE EXQUISITE SENSE OF TACT AND THE DOCTOR'S TOUCH}

If sight is both the paramount sense, the philosopher's sense, and also a crucial player-and-victim of the dismantling of hierarchies brought about by the Scientific Revolution, and other senses such as taste and smell are deeply embedded in (and saturated by) the cultural, religious, and affective fabric (scholars speak of a "permeability" of the senses in this period), we are still 
missing a crucial piece of the puzzle. We have alluded several times to the presence of a "hatred or phobia of touch" (e.g. Ficino in his commentary on the Symposium describing the lower senses such as touch as the source of "lust or madness": Gilman 1993: 201) ${ }^{8}$ or at least a depreciation of its value (as when Boyle calls it "the most dull of the five senses": Effluviums, Boyle 1772, III: 694). And conversely, we have mentioned the combination of praise and blame for organs like the hand, as in Bulwer. But we have left out the massive appeal to touch in the medical tradition.

If one recalls the old distinction, usually associated with Avicenna, between the via medicorum with Galen and the via philosophorum with Aristotle, it is striking that in the former touch is emphasized as important, especially the fingertips. Along with sight, touch was the most important diagnostic sense for Galen (Nutton 1993); for Fernel, touch was the best sense (Fernel 2003: 228, 230; Giglioni 2013). From this it is not a great step further to what MarieChristine Pouchelle calls the medical "rehabilitation of the flesh," with medieval surgery promoting "the solely secular value of the body" (Pouchelle 1990: 204), but also, the anatomical revival and the emergence of medical humanism, which both nourish Renaissance medicine-for example, the Padua school (Klestinec 2011; Mandressi 2003; Sawday 1994). The new emphasis on medicine in the Renaissance, with its re-evaluation of touch, has broader implications for a culture of touch, but also the emergence of a new kind of "embodied" empiricism (Salter and Wolfe 2009). Our own interest here in the ranking and hierarchy of the senses-here, touch-will appear more clearly once we have set out the medical situation in more detail. Two prominent cases of the medical privileging of touch are Harvey and Sylvius.

Touch was the pre-eminent bodily sense for Harvey: it is privileged in his inquiries. Harvey drew on touch because, as he wrote in A Second Essay to Jean Riolan, it offers more possibilities and is more powerful (Harvey 1958: 60ff.; Salter 2010). He spoke of the "powerful authority" of sense and experience as the "rule of the Anatomists" (or "anatomical habit"), founded on "touch and sight" as opposed to demonstrative reasoning "by causes and probable principles" (Harvey 1958: 58). He also emphasized the experimental and diagnostic priority of the "testimony of sight and touch" as regards generation-here, the womb: "It resembles the softness of the brain itself, and when you touch it, did not your own eyes give evidence to that touch, you would not believe your fingers were upon it" (Harvey 1653, Ex. 68: 415).

Sylvius follows Harvey in speaking of "the testimony of sight and touch," and personifies sight and touch as witnesses for Harvey's model of the heart's action against Descartes' speculations: "I bring forward a pair of faithful 
Witnesses of this Truth, which are enhanced with every qualification, Sight and Touch," these being the two paramount senses for anatomists (De febribus (1661), IX, 22, in Sylvius 1679). The two "faithful witnesses" testify that the arteries pulse and dilate whenever the ventricles of the heart contract, that the blood pours out from the heart with each contraction, and that a finger placed in the heart through a hole cut in the tip can feel the contraction. The testimony of touch, moreover, proves that the blood is poured out and a finger inserted in the dissected ventricles of the heart near the tip is sensibly compressed, whenever the aforesaid ventricles are contracted; and then at the same time the concurrent dilation of the arteries can be discerned by that same touch, through a hand brought up against them. ${ }^{9}$ Sylvius described Harvey as teaching according to the testimony of the senses, unlike Descartes, who "trusted more in the laws of his own Mechanics, rather than in his external Senses," and thought that "the Ventricles of the Heart and the Arteries were Dilated and Contracted simultaneously" (this empiricist-like criticism of Descartes was common amongst physicians in the later seventeenth and early eighteenth centuries, notably Steno and Boerhaave). Sylvius clearly elevates touch to be the equal of sight as an epistemic witness.

In other period contexts, the sense of touch is associated-consonant with Harvey and Sylvius-with learning about the world and the forging of the soul through the sensations of the body, as in Sir John Davies' philosophical poem Nosce Teipsum (1599):

By touch, the first pure qualities we learn,

Which quicken all things, hot, cold, moist and dry;

By touch, hard, soft, rough, smooth, we do discern;

By touch, sweet pleasure and sharp pain we try

Davies 1599, XVI: 45-6

It should not come as a surprise that touch, the basest of senses, can be praised. Touch is characterized by an essential ethical ambiguity: on the one hand, it was perceived as most common; on the other, as most necessary (Harvey 2011: 386-9).

Using the example of early modern prints depicting the human senses, Sharon Assaf argues vividly that the sense of touch perhaps most frequently evokes the erotic and seductive. Citing Badius' Stultiferae naves, an early printed book combining prose, verse, and woodcut illustrations, which she calls "the first text of the sixteenth century devoted to a moralizing appraisal of man's five senses” (Assaf 2005: 77), Assaf points out that Badius restated 
commonly-held notions about touch: that it is the last in the hierarchical ranking of the senses, that it is common to all living beings, and that it is spread throughout the body. Yet, at the center of the woodcut illustration is the hand. In each, the hand is perceived as the organ of touch, but in the former it is depicted as an offending appendage, whereas in the latter it is shown engaged in a worthy activity. In addition, the first print series devoted to the five senses by the Nuremberg Kleinmeister Georg Pencz presents the ambivalent meaning of the senses in the guise of nude female personifications, simultaneously seducing the viewer and presenting him with a moral lesson about each sense (Assaf 2005: 78).

Touching in its various guises-sexual, tender, exploratory, and, especially, creative and fashioning-appears in medieval and Renaissance poetry. Petrarch's word for Laura-scolpito, "sculpted or chiseled," also means "restored to wholeness," with a sexual connotation (Petrarch 1999: 543). In sonnets 32 and 51 of the Amoretti (Spenser 1999), Edmund Spenser the speaker compared his lady to iron "mollified with heate," then beaten, in order for her "stubberne wit" to be bent into shape he deemed appropriate. It is the fashioning of the lady not only through the poet's sexuality, but primarily through the power of his creativity, that is made to be the focus of the forging image. Early modern applications of the word in practical rhetoric seem to revolve around learning by being hurt, wounded, or tested by ordeal, giving touch a distinctly moral reading: "God hath touched me, that is, hath grievously smitten and wounded me. Another example, And they were pricked in their hearts (Act 2.) meaning, pearced with sorrow and repentance" (Peacham 1593: 7).

That poets, physicians, and other virtuosi can praise touch as an "exquisite sense," including in anthropocentric terms where it becomes a marker of our own superiority over the rest of the animal world, is noteworthy, not least given the initial privileging of sight we witnessed. "Of all the creatures, the sense of tact is most exquisite in man, because his body is most temperate," Alexander Ross declared in his 1651 Arcana microcosmi; Willis considered that "there should be many sensories in perfect animals," for the sake of selfpreservation and "propagation of their kind"; at the other end of the spectrum, the more "imperfect" animals, such as oysters and limpets, are "gifted only with the sense of touch." 10

Some recognize the importance of the "networked" character of touch, which is increasingly emphasized with the addition of musical (vibratory, harmonic) metaphors; Willis muses that even if touch seems "a faculty of a lower order," in some respects "it is more excellent by far than the rest," because it "receives and knows the impressions of many sensible things, and 
... so obtains a most large and ... general Province." 11 That touch "knows many things" or interacts with different sensory modalities-nose and skin, but also inner and outer, self and other (witness the numerous medical discussions of ticklishness) makes it something of a "common sense" (koine aisthēsis, sensus communis: Heller-Roazen 2007), or what we would call proprioception: "it is scarcely to be distinguished from the having of a body that can act in physical space” (O’Shaughnessy 2000: 658). This proprioceptive dimension was later highlighted by Condillac, for whom it was through this "fundamental feeling," touch, that we acquire a sense of ourselves, but also, that there is something existing outside of us (Condillac [1754] 1984, II.i.3: 158). Similarly, for D'Alembert, “touch undoubtedly teaches us to differentiate what is ours from that which surrounds us; it makes us circumscribe the universe to ourselves" (D’Alembert [1759] 1986, VI: 45). But this tactophilia is not a metaphysical-ethical valorization of this sense. For that, we need to turn finally to the materialism of touch.

\section{“IL N'Y A POINT DE PLAISIR SENTI QUI SOIT CHIMÉRIQUE": THE MATERIALISM OF TOUCH}

Let us distinguish two attitudes towards touch, not specific to either philosophy or "science": the reductionist and the holist. According to the former, the world is made of microparticles in motion. From heat to taste, from rain to sound, all the qualitative munificence on display in the Hypnerotomachias of this world is reduced to a quantitatively specifiable set of components and properties: "in those internal regions, there could be nothing but motion." But the holist attitude displays, as with the "common sense" theme, a fascination but also serious interest in the "network" or reticulated character of touch, crucial to our embodiment and its inextricable relation to our subjectivity, and to our successful functioning as agents in a potentially threatening natural world (something Descartes acknowledges clearly). When such non-materialist philosophers as Kant call it "the most fundamental sense" (Kant 1978: 63-4) and describe how "I am myself at my fingertips"-if not transcendentally, at least anthropologically (Traüme ein Geistesehers [1764], Ak II, 324), ${ }^{12}$ they are noticing the irreducibility of proprioception. This was undoubtedly why, for example, Berkeley rejected Descartes' description of the blind man "seeing through his staff": because vision could not deliver to us the spatial properties of objects, for which we need touch (An Essay Towards a New Theory of Vision, 1709; 4th edn, 1732). In addition, he felt that the program of mechanistically explaining our sensory functioning was doomed, because each 
of our senses evolves through experience, and the resulting totality is not something that can be arrived at mechanistically (Alciphron, 1732, IV, $\mathbb{1 1} 1 \mathrm{ff}$.).

Interestingly, both the reductionist and the holist conceptions of touch can be turned into a metaphysics, with different results (and one could map out where various figures fit: Galileo, Hobbes, and Descartes in one corner, Lucretius, Harvey, and Gassendi in the other, with in-between cases like Willis). Most significant in our view, not least because it is the boldest reversal of the "nobility of sight," preserving its valuative dimensions, is the latter, holist approach, which is Epicurean-Lucretian. Recall that for Lucretius, touch was the sense of the body itself, its self-possession. This was often used against the skeptical fear of the senses as "deceivers," asserting in contrast the "infallibility of sensitivity," that sensitivity "cannot lie." Epicurus held that reason was dependent on sensation, which was irrefutable; various separate perceptions guarantee the truth of our senses, and "if you argue against all your sensations, you will then have no criterion to declare any of them false." ${ }^{13}$ In the Lucretian version, this becomes infallibility: "there is no error in sense-perception" (Sextus Empiricus, Adversus Mathematicos, VIII.9; Lucretius, De rerum natura, IV, 474-99). Even Locke held that "This notice by our senses, though not so certain as demonstration, yet may be called knowledge, and proves the existence of things without us" (Locke 1975: IV.xi.3). Many of the clandestine manuscripts of the seventeenth and eighteenth centuries repeat these Lucretian topoi on how sensations cannot-or rarely-deceive us, sometimes with an extra hedonistic flourish (how could we be experiencing pleasure from something illusory, as in Diderot's "There is no pleasure felt that is illusory (chimérique))."14

The emergence of materialism brings with it a valorization of touch, notably in Diderot's 1749 Letter on the Blind. In Diderot's metaphysics of the senses, all the different senses "are just a diversified touch" and sight, the eidetic sense, is the idealist sense: "How deceptive the eye would be, if its judgment were not constantly corrected by touch." In contrast, touch becomes "the deepest, most philosophical sense," ${ }^{15}$ reversing the order of priorities in which the hands are "despised for their materialism." Yet this new respect for embodiment is not a mystification of "being-in-the-body": a materialism of touch is different from a phenomenology of body which often, as in Novalis, identifies touch with "the mystery of transubstantiation" (Novalis [1798] 1987: 622). ${ }^{16}$

When reflecting on the shift from a metaphysics of sight to a materialism of touch, one can ask under which historical conditions such transformations occurred-from the eye, divine and "like the sun" (from Plato to Grosseteste, $\mathrm{Du}$ Laurens and Goethe) to the praise of touch as more powerful (Harvey), 
exquisite (Ross) and excellent (Willis). And one could study current and crosscurrents of religiosity and secularization (including in the mechanization of vision), of profanity and transcendentalization (whether of sight, hearing . . . or the flesh). One could, as we have, strongly emphasize the central place of the via medicorum in this revalorization, and more metaphysically, point to the displacements effected by a modern Epicureanism, ultimately in the materialist reversal of the hierarchy of the senses. But our point was not that a sixteenthcentury Italian miller saw or "touched" differently than we do (Ginzburg 1980), although we hope to have described some of the variety of sensory regimes, but to investigate the gradual inversion of the privilege of sight into a materialism of touch-without which "nature remains like the delightful landscapes of the magic lantern, light, flat and chimerical," in Henri Focillon's words:

The possession of the world requires a kind of tactile flair. Sight slides along the universe, whereas the hand knows that the object has weight, is smooth or rough, and is not welded to the bottom of the sky or earth with which it appears to be joined ... Touch fills nature with mysterious forces; without it, nature remains like the delightful landscapes of the magic lantern, light, flat and chimerical.

Focillon 1943: 108, translation ours

\section{ACKNOWLEDGMENTS}

Thanks to Tawrin Baker, Benny Goldberg, and Brian Keeley for reading and critiquing an earlier version of this chapter; to Delphine Bellis, Guido Giglioni and Evan Ragland for their kind assistance. 


\section{NOTES}

\section{Introduction}

1. In a similar vein Barbara Rosenwein (2002) already dismissed the "grand narratives" of Huizinga, Febvre, and Elias from her own perspective, that of the history of emotions. The sensory historian Mark Smith speaks ironically of the "great divide" (Rosenwein 2002; M. Smith 2007: 8-13).

\section{Chapter One}

1. I would like to thank Iva Olah, whose discussion of ornament in Chapter 2 of her doctoral dissertation led me to this important attribute of Alberti's aesthetics.

\section{Chapter Five}

1. Although one can argue that what sight grasps for Aristotle is really just the form of the accidents inhering in the surface of a substance, not the essences themselves, which would be a more Neoplatonic reading. (Thanks to Tawrin Baker for this suggestion.)

2. See Hedwig (1972); Blumenberg (1993) and Ottaviani's (n.d.) useful lectures on medieval metaphysics of light.

3. Lev. 13:45; Vows; Deut. 22:5, Prohibitions (Idolatry). 'Commandments, The 613', Encyclopaedia Judaica, Vol. 5, C-DH (Jerusalem, 1971): 766, 772.

4. Kuchta (1993: 235-6). Note that transvestite conventions of the Elizabethan drama, allowing for a gender shift, are unique within early modern European acting conventions and codes of appearance (Orgel 1996: 2).

5. Descartes, Dioptrique (1637), AT VI: 141, 81 / CSM I: 152. Descartes is also part of the mechanist program to reduce all contact senses to touch, in Stephen 
Gaukroger's terms (introduction to Arnauld 1990: 17). See Descartes, Replies to Fourth Objections, AT VII: 251 / CSM II: 174; Rules \# 12, AT X: 412 / CSM I: 40).

6. Today, neural plasticity research indicates that a blind person can use the sight area of the brain to deal with tangible information (although see also Held et al. 2011; thanks to B. Goldberg for this reference).

7. Descartes, Dioptrique, 1er Discours (AT VI: 84 / CSM I: 153). For a comparison of the blind man in Descartes and in Diderot, see Le Ru (2000). For Lindberg it was a very old analogy, "already old in the ninth century" (Lindberg 1976: 39).

8. Gilman further notes that emblem books of the late Renaissance mostly represent touch "by an image of a woman touched or pierced by a wild animal" (1993: 206).

9. Thanks to Evan Ragland for his suggestions here.

10. Ross (1651, II.xxi: 110); Willis (1683, X (“Of the Sense in General”): 57, a point arguably going back to Aristotle's De anima II.2-3). Giglioni (2013: 19) cites Fernel and Ficino as holding this view.

11. Willis (1683, XI ("Of the Senses in Particular, and first of the touch"): 60); however (like Diderot later in his Paradoxe sur le comédien, 1769-78), Willis warns of the weakness of someone whose physiology would be constantly at the mercy of their sensitivity. (For a brilliant and evocative discussion in contemporary neurobiological terms of why "it would not be a good idea" to perceive in total, synesthetic and hallucinatory terms, see Freeman 1991.)

12. Kant also discusses Cheselden's cataract experiments in his anthropology lectures.

13. Diogenes Laertius 1959, X, 32; Epicurus, Principal Doctrines, 23, in Long (1986: 21) (further elaborated in Cicero, De natura deorum, I, 70 and De finibus, I, 30, 64).

14. Le pour et le contre, III, in Diderot (1975-, XV: 9). Shaftesbury described our sensations as real regardless of the status of the objects in his Inquiry Concerning Virtue or Merit (which Diderot translated): "For let us carry scepticism ever so far, let us doubt, if we can, of everything about us, we cannot doubt of what passes within ourselves. Our passions and affections are known to us. They are certain, whatever the objects may be on which they are employed" (Shaftesbury 1964, I: 336-7).

15. Enc., art. "Epicuréisme," V: 782a; Éléments de physiologie, in Diderot (1975-, XVII: 457); Lettre sur les sourds et muets, in Diderot (1975-, IV: 140).

16. We have in mind thinkers as diverse as late Husserl, Merleau-Ponty, Didier Anzieu and his notion of the "Moi-Peau" ("I-skin"), and Jean-Luc Nancy, with his "secularized Christian" fascination with embodiment qua incarnation. They seem to repeat the powerful mystical utterances of figures such as the twelfth-century nun Hildegard of Bingen and the thirteenth-century Flemish poet and Beguine, Hadewijch. Of course, one need not have a hyper-transcendentalized self, I, or body to arrive at a rich concept of embodiment and touch: consider J.J. Gibson's "rich" or "thick" account of perception, in which touch is not a mere contact sense but something more dynamic, involving more "intentionality" (Gibson 1966: 102, 132ff.), which partly resonates with Alois Riegl's notion of a "haptic" dimension of art (i.e., based on touch), versus its optic dimension (Riegl [1901] 1985). 